\title{
Hamas: Struggle from the Cradle to the Last Drop of Blood (Malay Version)
}

\section{Iqbal $\mathbf{U}^{*}$}

History Programme, Faculty of Social Sciences and Humanities, National University of Malaysia, Malaysia

*Corresponding author: Iqbal U, History Programme, Faculty of Social Sciences and Humanities, National University of Malaysia, UKM 43650, Bangi Selangor, Malaysia, Tel: 60389215555; E-mail: uqbah@siswa.ukm.edu.my

Received date: April 25, 2016; Accepted date: April 26, 2016; Published date: April 28, 2016

Citation: Iqbal U (2016) Hamas: Struggle from the Cradle to the Last Drop of Blood (Malay Version). Arts Social Sci J 7: 174. doi: 10.4172/2151-6200.1000174

Copyright: (c) 2016 Iqbal U. This is an open-access article distributed under the terms of the Creative Commons Attribution License, which permits unrestricted use, distribution, and reproduction in any medium, provided the original author and source are credited.

\section{Opinion}

The issue of Palestine is the issue of Muslims worldwide. This is because there is the first Qibla of Muslims and also a place of Isra' and Mi'raj, the al-Aqsa Mosque. Palestine is also the land of Muslims from the time of Solomon again. It then turns colonized by Jews, Romans and Persians until the time of Umar al-Khattab, Palestine back into the possession of Muslims. At the beginning of the 12th century AD Palestine occupied again by the Crusaders, but finally liberated by Salahuddin al-Ayubi. Now since 1948 Palestine were colonized by the Jewish zionist regime. Media controlled by the West and the Jews also called Muslims in Palestine as a terrorist group that harassed the Jews who are the real people of Palestine.

Jews area are increasingly wide, now only a few regions only for Muslims namely the Gaza Strip, Tel Aviv, Haifa, Ramallah, Jerusalem and Bethlehem. Hamas in the struggle to free Palestine is a great jihad to defend Islam. The role of the Hamas movement should be studied carefully by readers to be a motivation in the fight.

This book is a description of the history and role in the Hamas movement to free Palestine. Hamas is an acronym for "Harakat alMuqawama al-Islamiyyah' which means 'Islamic Revival Movement' is a Palestinian Islamic organization that was once the party came to power in Palestine since it election victory in January 2006. At that time its leader, Isma'il Haneyyah was appointed the Palestinian Prime Minister. But on June 14, 2007, Palestinian President Mahmoud 'Abbas has dissolved the parliament and sacked the Palestinian Unity Government led by Hamas in fighting between Hamas and Fatah in the Gaza Strip. 'Abbas appointed Salam Fayyad as Haneyyah's substitute.

Hamas was founded by Sheikh Ahmad Yassin from the Muslim Brotherhood Gaza Strip branch. Since its establishment, Hamas has been launching attacks against Israelis, the Palestinian territories conquered country. Hamas's charter calls for the state of Israel to be destroyed and replaced with a Hamas Islamic state that showed antiIsrael sentiment and fight to expel the Israelis out of Palestine through jihad.

Hamas is considered a terrorist group by the United States, Canada, United Kingdom, Australia, Israel, Japan and the European Union. In June 2007, the Hamas militant gained control of the entire Gaza Strip and destroy the influence and power of Fatah in the area. For those who value history, Israel is not recognized. Land of Israel belongs to Palestinian sovereignty. Britain controlled Palestine after the fall of the
Ottoman Caliphate following the First World War held it as a mandate, namely trust. Therefore in democratic way, it must return to the Palestinians. If the Palestinians want an independent and sovereign state, then that is what should be created.

This book will reveal the extent of the role of Hamas in trying to liberate the land of Palestine and called on Muslims to assess whether Jews act rationally, where they still do not even recognize Hamas won the elections of 2006. Looking at the superiority and excellence of Hamas movement in the struggle to liberate Palestine from the further gripped of occupier, the author interested to study the backgrounds and roles of the movement that make they are willing to die a martyr in the cause of God than submit to the cruel power. The struggle waged by the Hamas movement is simply to get back Jerusalem from the hands of the Jews. Palestine is not simply the Palestinians and Arab affairs only, but Muslims common problems.

Although there is a lot of writing about Palestine before, but so much of that writing only touched in passing on the role of the Hamas movement in the struggle for the liberation of Palestine. This is because the discussions that produced mostly general in nature or focused on the ideology of Hamas and the struggle waged by the movement without explaining or specialize to the actual role of this movement, and then this book role is important. The book is expected to benefit readers with some background information highlighting the role of Hamas, apart brighten the spirit of jihad among Muslims in order to participate in any way to help Muslims in Palestine.

This book also describes the organizational leadership of Hamas. Selected figures are Sheikh Izzuddin al-Qassam who contribution recognized through the name of Brigate al-Qassam and Hamas rockets invention known as al-Qassam rockets, Syeikh Ahmad Yassin who is an icon of Hamas, Dr. 'Abdul 'Aziz al-Rantissi, Syeikh Solah Syahadah who is the founder of Izzudin al-Qassam Brigades, Mahmoud Zahhar, Ibrahim Maqadmah and Isma'il Abu Shanab, Khaled Mesh'al who led the Hamas political bureau, Isma'il Haneyyah, Jamal Mansour, Yahya 'Ayyash and Musa Mohammad Abu Marzouq.

According to a Palestinian Issues activist, Maszlee Malik, we all can express our love to Palestine through a variety of ways. We can help with organizing creative programs to mark al-Quds in danger in the community. "Masjid al-Aqsa in dire need of prayer from us all" Continue to pray and work. It's time for us to prove that al-Aqsa is very important in our hearts. 